Article

\title{
Precipitation Variability and Probabilities of Extreme Events in the Eastern Mediterranean Region (Latakia Governorate-Syria as a Case Study)
}

\author{
Ahmad H. Y. Abu Hammad ${ }^{1, *}$, Ala A. M. Salameh ${ }^{2}$ and Riad Qara Fallah ${ }^{3}$ \\ 1 Department of Geography and Geoinformatics, Birzeit University, P.O. Box 14, Birzeit P627, West Bank, Israel \\ 2 Departamento de Física Aplicada, Universidad de Granada, 18071 Granada, Spain; alasalman84@correo.ugr.es \\ 3 Department of Geography, University of Tishreen, Latakia 2230, Syria; riadqarafallah@gmail.com \\ * Correspondence: ahammad@birzeit.edu; Tel.: +972-2-298-2938; Fax: +972-2-298-2981
}

check for updates

Citation: Abu Hammad, A.H.Y.;

Salameh, A.A.M.; Fallah, R.Q.

Precipitation Variability and

Probabilities of Extreme Events in the

Eastern Mediterranean Region

(Latakia Governorate-Syria as a Case

Study). Atmosphere 2022, 13, 131.

https://doi.org/10.3390/

atmos13010131

Academic Editors: David Reed and

Ari Preston

Received: 14 December 2021

Accepted: 6 January 2022

Published: 14 January 2022

Publisher's Note: MDPI stays neutral with regard to jurisdictional claims in published maps and institutional affiliations.

Copyright: (C) 2022 by the authors. Licensee MDPI, Basel, Switzerland. This article is an open access article distributed under the terms and conditions of the Creative Commons Attribution (CC BY) license (https:// creativecommons.org/licenses/by/ $4.0 /)$.

\begin{abstract}
This study aimed at analysis of the general-index change for the mean annual and seasonal precipitation in six stations in Latakia Governorate (Syria). The data of precipitation were collected for 40 consecutive years (1970-2010) in order to figure out the extent of the changes and variability in precipitation rates and the impact of this change on changes in the potential density that might cause extremely high or low precipitation rates according to Gumbel distribution of the extreme precipitation rates. Results revealed a decrease of the annual precipitation rates in all stations, the reduction in precipitation ranged from 46 to $210 \mathrm{~mm}$ during the whole period of the study. Spring, however, recorded the highest and statistically significant reduction, which reached 46-210 mm, while winter precipitation increased by 21-82 $\mathrm{mm}$. Spring also has witnessed a decrease of about $3-9 \%$ of the total annual precipitation as compared to winter precipitation which increased by $5-8 \%$ of the total. The potential density of extremely high winter precipitation rates increased in all stations as indicated from Gumbel distribution in winter, and a greater increase took place in the probabilities of occurrence of the extremely low spring precipitation rates. This shows significant probability of occurrence of drought during spring season. By contrast, probabilities of winter precipitation rates increased more, thus winter is relatively more humid than before and spring is relatively drier than before.
\end{abstract}

Keywords: climate change; Gumbel distribution; extreme precipitation; Latakia; probability of occurrence; eastern Mediterranean

\section{Introduction}

Fluctuations in precipitation could cause socio-economic and natural problems [1,2] such as reduction in agricultural areas and its effect on related economic and social aspects. Additionally, the climate change variability or the change of the climate system, specifically rainfall, directly affects the hydrology of an area as well as the general hydrologic cycle [3-5]. Since the late seventies, the increase in the average global mean temperature caused an increase in the events with extreme climate conditions such as the temperate in tropical areas [6-8]. Increasing temperatures also led to higher rates of evapotranspiration and increased the plant water requirements [9]. On global and regional scales, many studies forecasted a greater increase in extreme events of precipitation that is related to the current global warming, especially when such precipitation is compared to the mean values $[10,11]$.

During the last three decades, many studies have indicated a decreasing trend in precipitation and an increasing in temperature trends over the Mediterranean and Middle East regions [12-20]. This climate change is considered also as a main driving factor for the occurrence of more drying conditions in the Mediterranean region [20-22]. On the other hand, the accelerated development and urbanization processes into the Levant countries, has caused more climate changes with related soil degradation, desertification, 
water scarcity, overpopulation, and large-scale changes in land use and land cover [23]. In total, such changes brought further pressure on the available and limited natural resources, especially land and water.

The precipitation in the Mediterranean region is characterized by irregular distribution in both temporal and spatial terms. Of this precipitation, $55 \%$ of its total water resources that equals to $600 \mathrm{~km}^{3}$ /year occurred in Turkey and Northern Mediterranean Countries, while southern and eastern Mediterranean countries suffer from chronic shortage of water up to $100 \mathrm{~m}^{3}$ / person/year, in some parts of the Mediterranean the shortage could reaches $500 \mathrm{~m}^{3} /$ person/year [24]. In eastern Mediterranean (EM) region, the reduction is about $20 \%$ from annual rainfall that is expected by the year 2050 [25-27]. For example, Syria is one of the countries that are more vulnerable to climate change due to the dependence of more than $62 \%$ of its agricultural lands (equivalent to about $14,258 \mathrm{~km}^{2}$ ) on rainfall as the main source of plant requirements [28]. In addition, rainfall represents $68.5 \%$ of all available water resources, and the agricultural water requirements were expected to increase by $6 \%$ in 2020 [29]. Jordan is considered the fourth poorest water-resourced country. According to the Ministry of Water and Irrigation (MWI), water availability has declined from $3600 \mathrm{~m}^{3}$ /year per capita in 1946 to $145 \mathrm{~m}^{3} /$ year per capita in 2007 [30]. This may be important particularly in rainfed areas, like Syria; due to the lack of irrigation possibilities.

The Arab Forum for Environment and Development indicated that the Arab countries contain less than $1 \%$ of the world's freshwater volume, despite the fact that the area of the Arab countries reaches $10 \%$ of the total world land area. These countries, including Syria, suffer from chronic shortage of water because of the lack of rainfall and water resources. In addition, the increase in mean annual temperature affected these countries, where an increase in drought accompanied by a decrease in the mean annual precipitation occurred, with a repeated and successive drought periods that has not been reported in the past. Such changes made it important to identify the differences in precipitation amount and its extreme rates and events, which could affect some key sectors including agriculture, and though the results could help in securing enough water for different activities. In Lebanon, Hussein found that the water discourse and crisis in Lebanon is often addressed as a national security issue, and that the issue of water scarcity in the country is strongly related to transboundary water control and governance. In addition that the Syrian Refugee in Lebanon created tensions due to blaming the refugees as the cause of water scarcity, unemployment and instability in Lebanon [31]. Zeitoun found that water in the Middle East provides a powerful new perspective on the Palestinian-Israeli water conflict. Zeitoun adopted a new approach to understand this water conflict. He showed that the conflict is much deeper than one thought, and he revealed negative relationship between existing tactics to control water and the possibility to make peace; especially with the continued domination of water resources by the stronger countries. Such domination tend to play down negative effects on peaceful and non-violent water-related issues and conflict, leaving weak or no cooperation between countries often and could cause serious conflict between them. This hydro-hegemony reveals the hidden changes and dynamics of water conflict into the Middle East water problem [32].

Knowledge on the effect of regional climate changes, on temperatures changes and precipitation averages, is not the only reason to study the importance of such data on climate change, changes in extreme values of precipitation and its probabilities is also important [33]. Low amounts of precipitation is one of the key features of extreme weather events with which drought could increase, which signifies its effects in a region that is originally suffering from the lack of water resources and has extreme summer drought. This requires taking all precautionary measures to counteract the effects that may cause this change. The Arab Forum for Environment and Development (AFED) and the Intergovernmental Panel on Climate Change (IPCC) [6,34] reported that the increasing drought as a result of increasing temperature will increase the need for irrigation water, and the crops rotation and periods will ultimately change. 
To understand the precipitation changes and occurrence of drought in the study area, a study has been done to achieve the following objectives:

(i) To analyze the general trends of the mean annual and seasonal precipitation in six weather stations of Latakia governorate during the period (1970-2010);

(ii) To quantify the mean annual precipitation change with its statistical significance;

(iii) To identify which seasons and periods have witnessed the highest changes in precipitation; and

(iv) To analyze the changes in the probabilistic density of extreme rates using Gumbel distribution of extreme precipitation events.

\section{Methodology}

This research depends on the monthly rainfall for the period 1970-2010 and in six weather stations in Latakia governorate, which is located on the coastal region of Syria (Figure 1). The weather stations have different altitudes ranging from $7 \mathrm{~m}$ to $1173 \mathrm{~m}$ above sea level (Table 1). The stations are Latakia, Al- Qirdaha, Al- Hafa, Salanfa, Qastal alMa'af, and Al- Basel Airport (Figure 1).

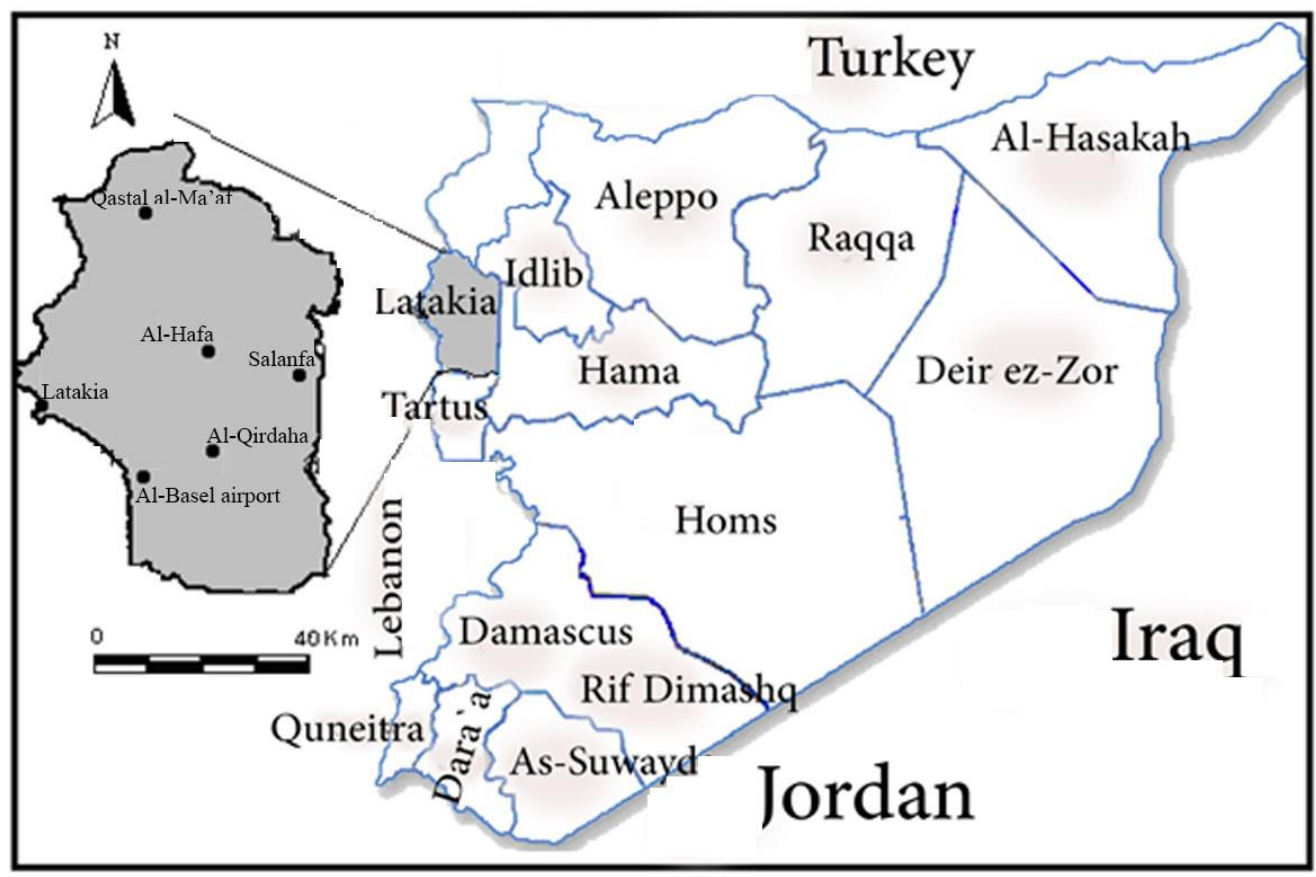

Figure 1. Location of Latakia Governorate in Syria, with the location of the six weather stations.

Table 1. Names, locations, and altitudes of weather stations used in the study area.

\begin{tabular}{cccccc}
\hline Weather Station & Latitude & Longitude & Altitude & Station Type & Available Rainfall Data Time Series \\
\hline Latakia & 35.78 & 35.52 & 7 & S $^{1}$ & $2010-1970$ \\
\hline Al- Basel airport & 35.94 & 35.41 & 48 & S & $2010-1970$ \\
\hline Al- Qirdaha & 36.05 & 35.45 & 300 & S & $2010-1970$ \\
\hline Al- Hafa & 36.05 & 35.61 & 335 & C $^{2}$ & $2010-1970$ \\
\hline Qastal al- Ma'af & 35.94 & 35.83 & 675 & C & $2010-1970$ \\
\hline Salanfa & 36.19 & 35.57 & 1173 & C & $2010-1970$ \\
\hline
\end{tabular}

Source: General Directorate of Meteorology-Syria. ${ }^{1}: \mathrm{S}$ denotes synoptic station at which observation are made for the purpose of synoptic analysis. ${ }^{2}$ : C denotes climatic station at which normal measurements of different climatic parameters that used for local or regional analysis. 
Latakia governorate was chosen as a case study because of the availability of enough and well-distributed meteorological stations over the whole area of the governorate. This will prevent insufficiencies of case selection by randomization; hence the selection of purposive case (Latakia) will be though strong. Such purposive selection can make an important contribution to the inferential process of climate change by enabling the application of the results to the whole area of case study (Latakia) as well as any area with similar conditions and circumstances [35].

Time series linear regression equation was done to reveal changes in the general slope of the general precipitation trend line, and therefore changes in the seasonal and annual precipitation, including the statistical significance of such changes. The data was then divided, based on the seasons, into two time series; the first time series is from 1970 to 2000 (31 years), and the second time series is from 2001 to 2010 (10 years). Such division was done in order to identify the changes in the mean precipitation during the first decade (10 years) of the twenty first century as compared to the last three decades of the last century (31 years), because the 31 years period represents by itself a climatic cycle. The reason behind choosing two time series is that 11 years out of 12 years within the period (1996-2005) had the highest average temperatures since the beginning of the global temperature measurements in 1850 (according to the report of the Intergovernmental Panel on Climate Change [6]. The following measurements of the IPCC indicted also that the years from 2007 and beyond were hotter, and its peak occurred in 2010 that is considered the highest in the historical global temperature measurements.

The $t$-test was conducted to measure the statistical significance of the changes in the mean annual precipitation (2001-2010) compared to the mean for the period (1970-2000), with a $95 \%$ degree of confidence and according to the following formula:

$$
t=\frac{\bar{X}_{1}-\bar{X}_{2}}{\sqrt{\frac{\sigma_{1}^{2}}{n_{1}}+\frac{\sigma_{2}^{2}}{n_{2}}}}
$$

where:

$X_{1}$ and $X_{2}$ : The averages of the precipitation during the two time-periods.

$\sigma_{1}$ and $\sigma_{2}$ : The standard deviation of the precipitation during the two time-periods.

$n_{1}$ and $n_{2}$ : The number of years in each time-period.

Gumbel distribution was used to analyze the potential density of extremely high and low precipitation rates, because its effect is identified from two directions [36]. This distribution has significant importance in hydrological and climatic studies, which depends on studying the effect of rainfall intensity on drought or flood periods [37], therefore the possibility of storing water in wet periods and using it in droughts period for irrigating plants and for other different uses. Gumbel distribution is calculated using the following formulas [38]:

$$
F(x)=e^{-e^{\frac{(x-c)}{d}}}
$$

where: $c=\bar{X}-0.5772 . d$ and $d=\frac{\sqrt{6}}{\pi} s_{x}=0.7797 . s_{x}$

$S_{x}$ Standard deviation of precipitation

$x$ Amount of precipitation

$\bar{X}$ Arithmetic mean for precipitation

In the calculation of Gumbel distribution, the area under the distribution curve equals to 1 unit or $100 \%$; as the increase in the arithmetic mean for precipitation causes accompanied changes in potential density of precipitation, especially the extreme ones. This change is clear when compared with previous time-periods (Figure 2A). Figure 2A shows the changes in the precipitation averages in a hypothetical station during two periods. The figure reveals an increase in the flattening of the grey curve that represents today's climate (the most recent time-period). Such flattening caused an increase in the scattering of the precipitation and an increase in its standard deviation from the averages, which means an increase in the probability of extremely low rains occurrence, which is equal to 
$200 \mathrm{~mm}$ in Figure 2A. Moreover, the increase in the probability that precipitation reaches amounts more than $600 \mathrm{~mm}$ as compared to the amounts in previous time-period can also be calculated. Figure 2B shows an increase in precipitation average where the probabilities of extremely high rain has increased and at the same time the probabilities of extremely low precipitation has decreased. The current research will focus on extremely high or low precipitation averages which constitutes either more than or less than $10 \%$ of the total annual rainfall [39] during the period from 1970-2000, and at the same time to observe the probabilities of rainfall change in second time-period from 2001-2010.

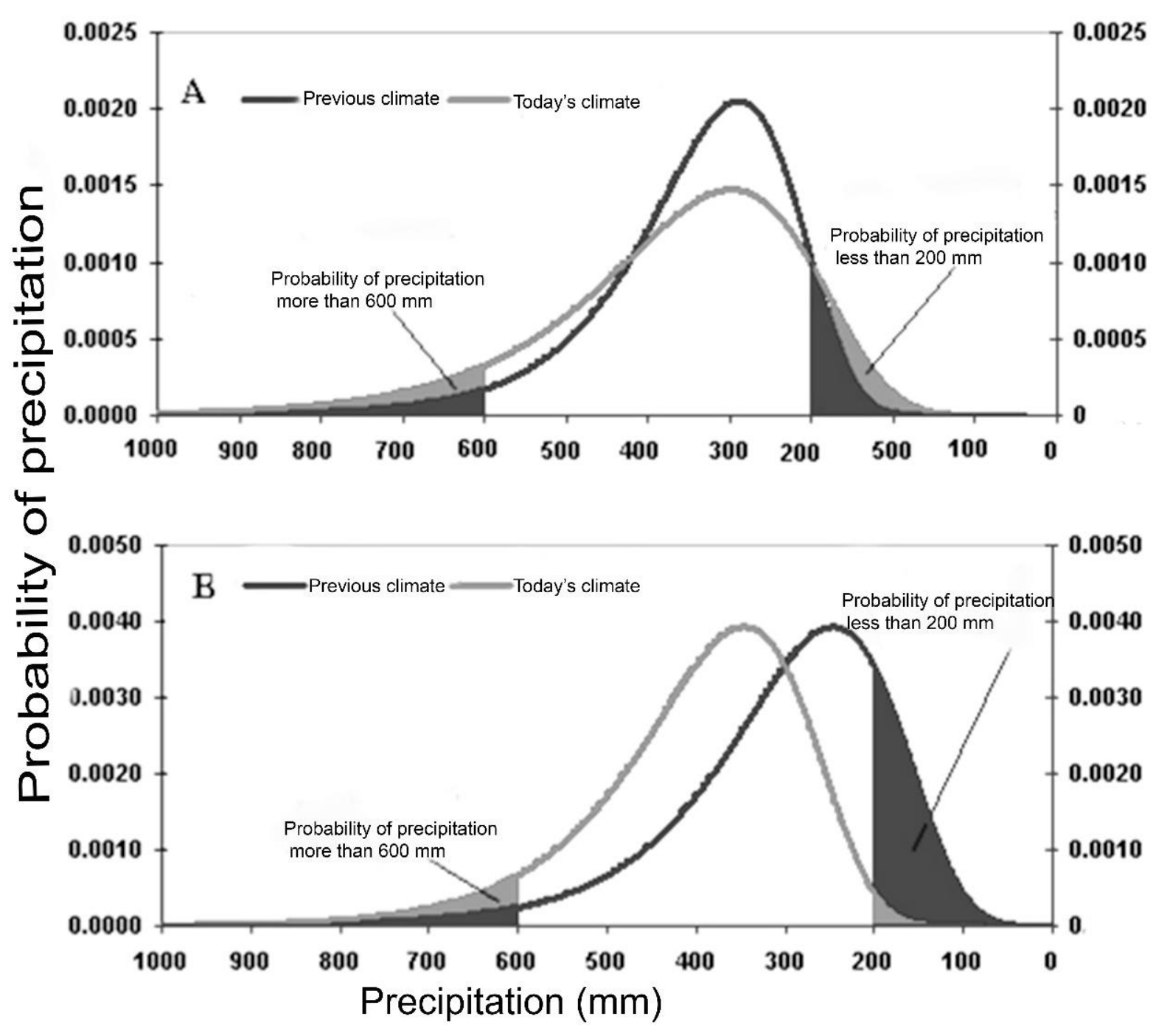

Figure 2. Two different models for Gumbel distribution to compare precipitation changes between two time-periods (A): probability of extremely low rains and (B): probabilities of extremely high rains.

\section{Results and Discussion}

Generally speaking, a decrease in the annual precipitation regression line during the first period 1970-2010 for the six meteorological stations is observed. Figure 3 shows a moderate decrease in annual precipitation amounts from the beginning of the first period (1970), which reached $125 \mathrm{~mm}$ in Latakia station, $175 \mathrm{~mm}$ in Al- Basel airport, $52 \mathrm{~mm}$ in al- Qirdaha, $75 \mathrm{~mm}$ in Salanfa. The highest and riveting decline occurred in Al-Hafa and Qastal al-Ma'af stations, with an annual decline rate of $325 \mathrm{~mm}$ and $263 \mathrm{~mm}$, respectively. 

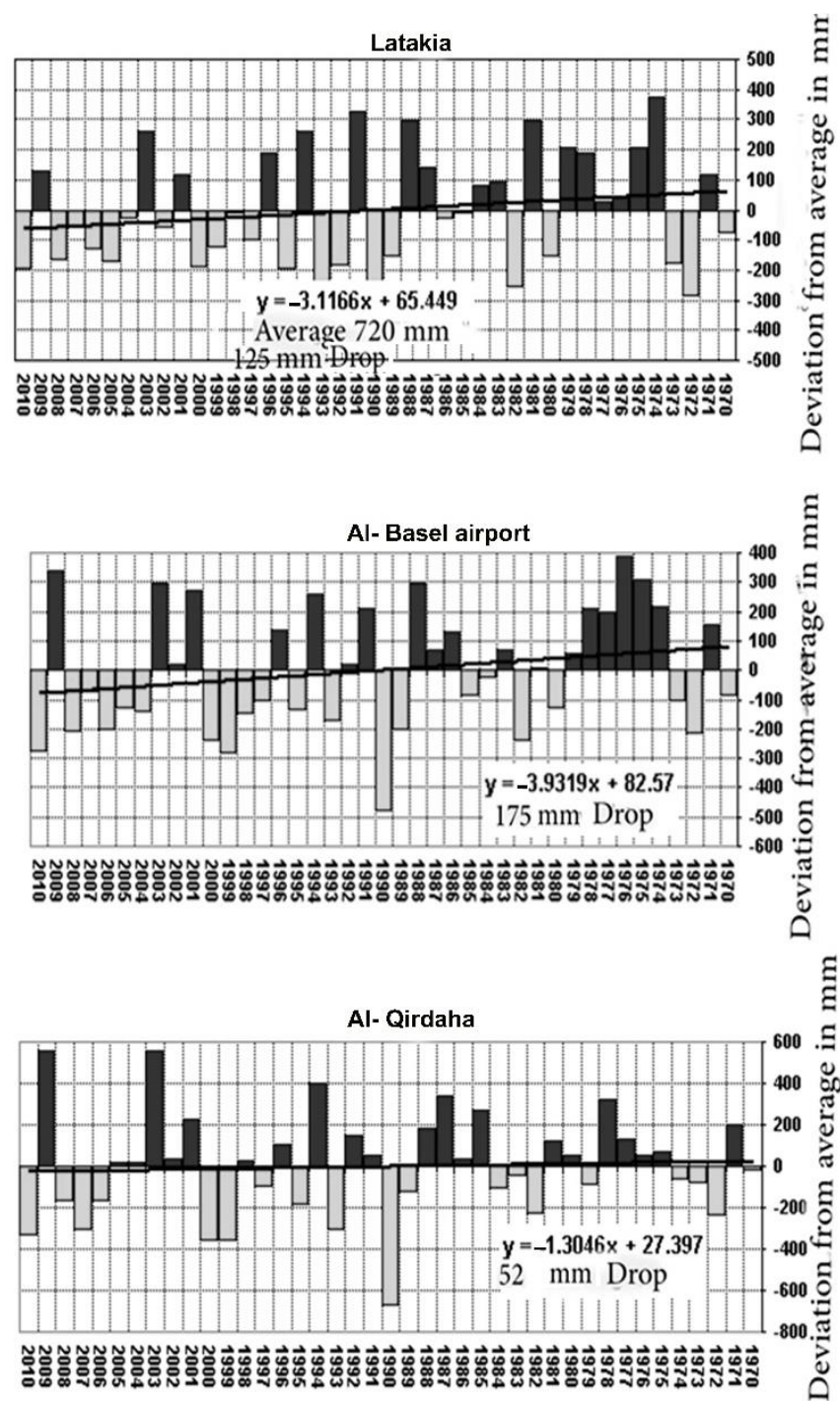

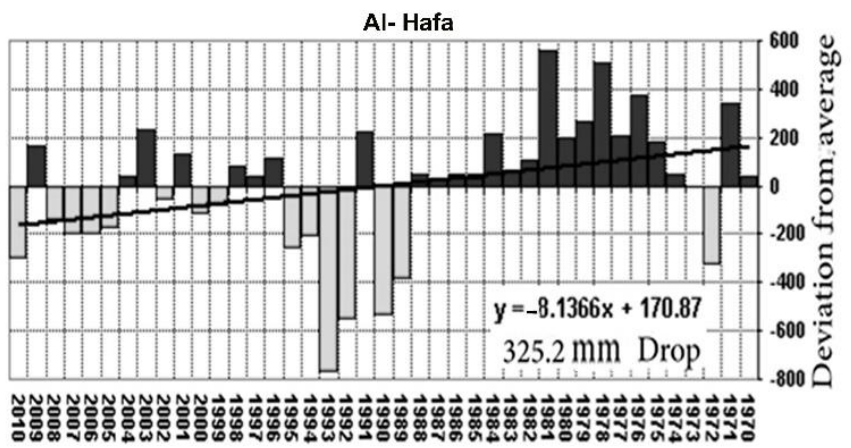

Qastal al- Ma'af

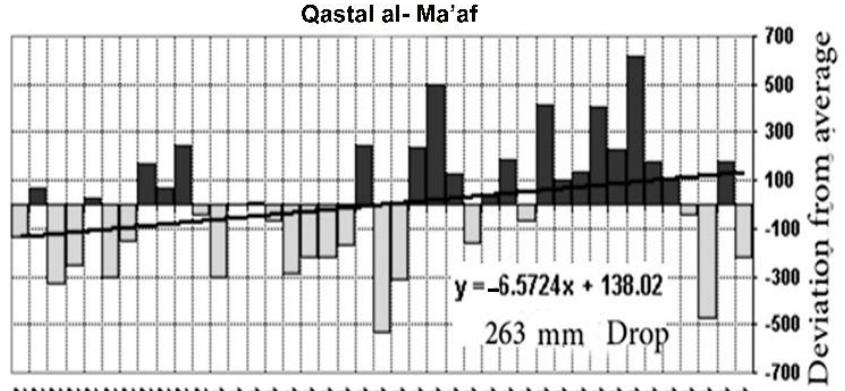

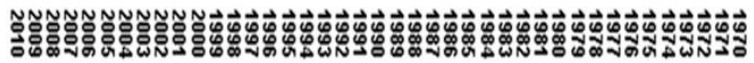

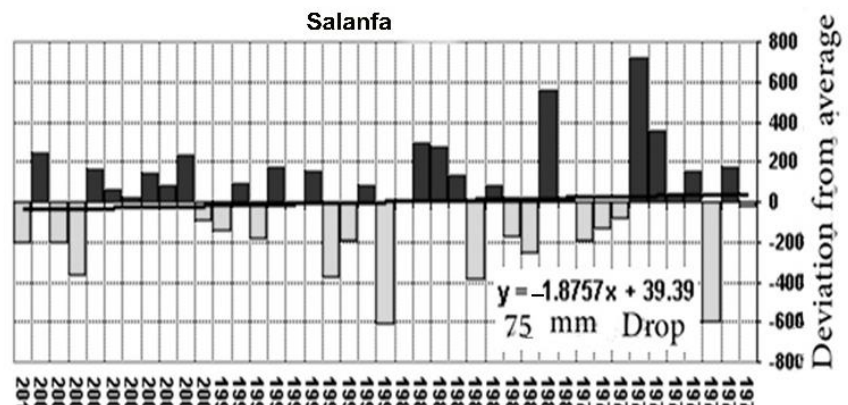

Figure 3. General trend of the mean annual precipitation from 1970-2010.

Table 2 shows no large change in the mean annual precipitation during the second period from 2001-2010 as compared to the first period from 1970-2000, and this is mainly because the precipitation rates in all the stations witnessed a minor decline ranging from 14-79 mm, however this decline was not statistically significant. The stations that witnessed a slight increase in the precipitation rate are Salanfa and al- Qirdaha stations (23 $\mathrm{mm}$ and $58 \mathrm{~mm}$, respectively) but the increase was not statistically significant (Table 2). Prominent statistically significant decline in the slope of the precipitation regression line is noticeable during spring season in all the stations. This decline reached its maximum in Al- Hafa station with $210 \mathrm{~mm}$ decline during the whole period of the study (1970-2010); with an average annual decline of $5.3 \mathrm{~mm}$. The second station in decline of rainfall occurred in Qastal al- Ma'af with a total decline of $164 \mathrm{~mm}$ during the entire period and an average annual decline of $4.1 \mathrm{~mm}$. The decline in al- Qirdaha station during spring reached $116.4 \mathrm{~mm}$ (2.9 mm/year) and it was statistically significant. Similarly, a statistical significance decline in spring precipitation in Latakia that reached $86.1 \mathrm{~mL}(2.2 \mathrm{~mm} /$ year $)$. Statistical decline in the precipitation average during spring season was evident in all the stations. The second important change was during winter in all the stations; where there were increases in the precipitation ranged from 20 to $86 \mathrm{~mm}$ in the second period (2001-2010) compared to the first period (1970-2000), however the increases were not statistically significant. 
Table 2. The slope of the regression line for precipitation and the statistical significance of the slope of the precipitation regression line with the averages.

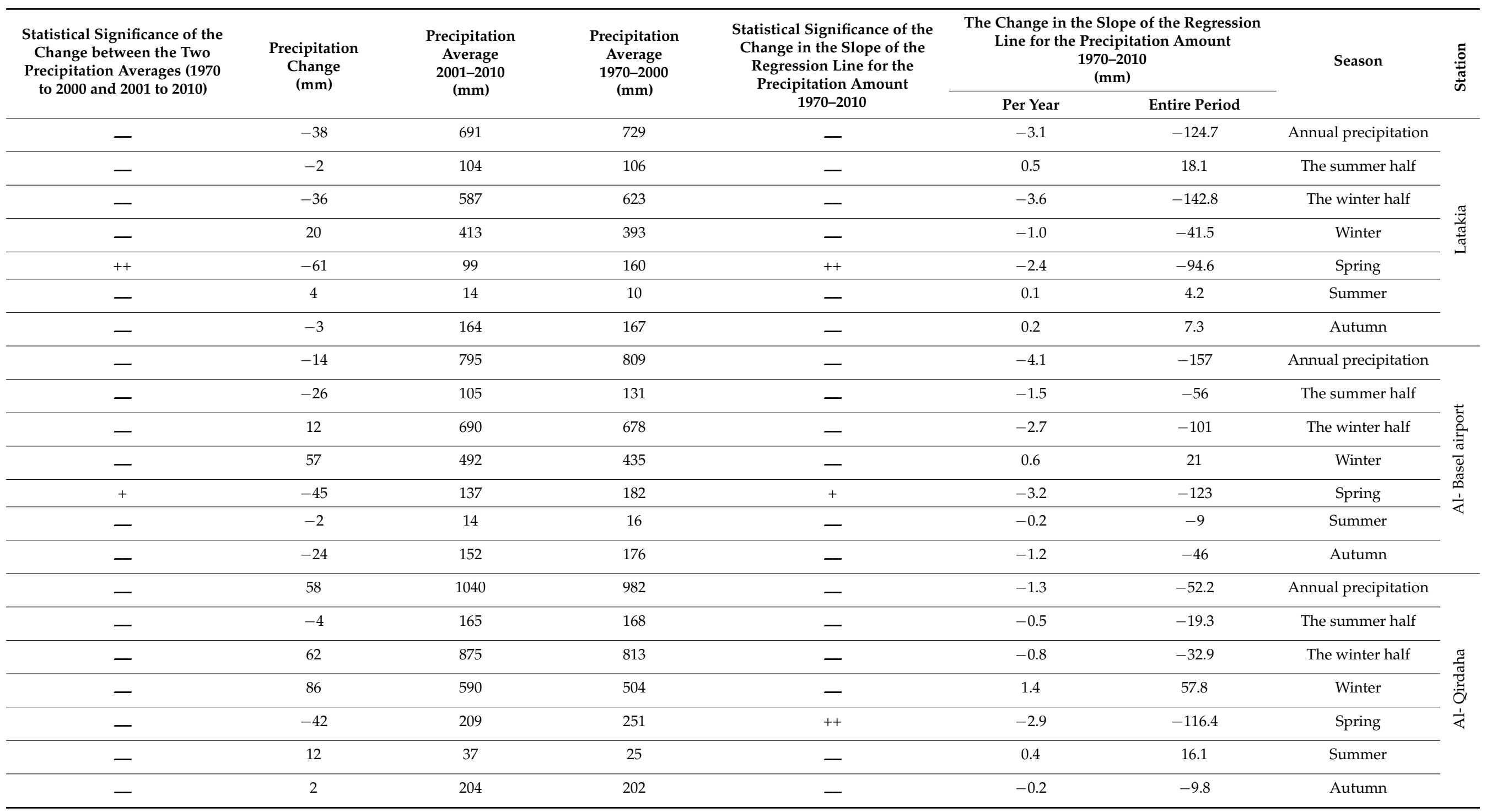


Table 2. Cont.

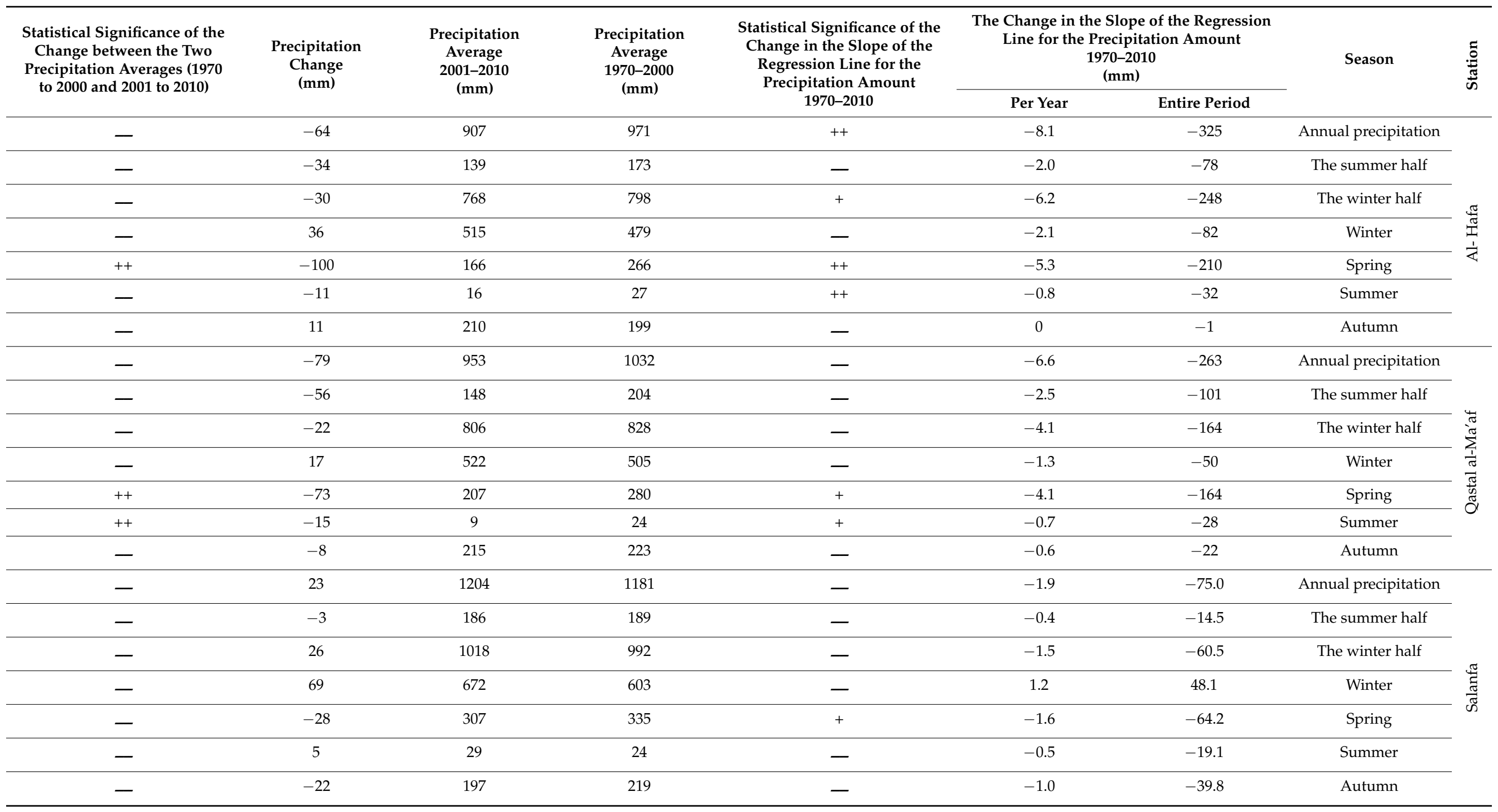

(+): Significant at the 95\% level; (++): Highly significant at the $99 \%$ level; (_): Statistically insignificant. 
Generally speaking, Table 2 shows a strong and negative change in the slope of the precipitation regression line in all the stations. Such changes are due to the reduction in the mean annual precipitation in the second period (2001-2010) compared to the first period. The exception is in al- Qirdaha and Salanfa stations where there was slight increase in the average annual precipitation.

Abu Hammad found a reduction in the annual precipitation in Jerusalem Governorate during the period from 1980-2018. The reduction in precipitation was more in winter season compared to spring season, but both reductions (winter and spring) were statistically significant. The results are similar for spring season as the current study although in Abu Hammad's study, the reduction was significant, but in this study the reduction is not statistically significant during winter but significant during spring season. The difference in significance between both studies might be due to different spatial characteristics of the tow study areas. In Latakia governorate, it is considered as a coastal and semi-coastal area with quasi-humid climate; as a result, any change in precipitation should be large enough to show significance. In Jerusalem governorate (Palestine), it has a semi-arid climate with lower precipitation compared to Latakia, hence, any change in precipitation even if it is small will show statistical significance compared to the total annual precipitation $[40,41]$.

The decline in the spring precipitation and the increase in the winter and autumn precipitations caused a relative difference in the distribution of precipitation during different seasons (Table 3). Table 3 shows that the spring's share from the total annual precipitation declined by about 3-9\%, compared to an increase in winter precipitation rates between $5-8 \%$. The most and prominent change was in Al- Hafa station that witnessed a decline in spring rainfall by $9 \%$, and an increase in winter rainfall by $8 \%$. A study on the climate of Palestine and its changes has ensured an increase in the temperature and drought periods by about $0.74{ }^{\circ} \mathrm{C}$ during the period from 1905-2010, which provides a further indication of the existing change in climatic condition. The study also revealed changes in the mean annual rainfall $[12,14]$. Trevor also found that winter season rainfall over the northern part of the Mediterranean has decreased over the last four decades [42]. The decline is almost similar to what has been found in the current study, the decrease has been explained based on the local enforcement by the decrease in the intensity of cyclogenesis events in the Mediterranean region.

Table 3. Percentage of seasonal precipitation from the total during the two periods (2001-2010 and 1970-2000).

\begin{tabular}{|c|c|c|c|c|c|}
\hline Autumn & Summer & Spring & Winter & $\begin{array}{l}\text { Precipitation Percentage } \\
\text { during the Two Periods }\end{array}$ & Station \\
\hline $23 \%$ & $1 \%$ & $22 \%$ & $54 \%$ & 1970-2000 & \multirow{2}{*}{ Latakia } \\
\hline $24 \%$ & $2 \%$ & $14 \%$ & $60 \%$ & 2001-2010 & \\
\hline $22 \%$ & $2 \%$ & $22 \%$ & $54 \%$ & 1970-2000 & \multirow{2}{*}{$\begin{array}{l}\text { Al- Basel } \\
\text { airport }\end{array}$} \\
\hline $19 \%$ & $2 \%$ & $17 \%$ & $62 \%$ & 2001-2010 & \\
\hline $21 \%$ & $3 \%$ & $26 \%$ & $51 \%$ & 1970-2000 & \multirow{2}{*}{ Al- Qirdaha } \\
\hline $20 \%$ & $4 \%$ & $20 \%$ & $57 \%$ & 2001-2010 & \\
\hline $21 \%$ & $3 \%$ & $27 \%$ & $49 \%$ & 1970-2000 & \multirow{2}{*}{ Al- Hafa } \\
\hline $23 \%$ & $2 \%$ & $18 \%$ & $57 \%$ & 2001-2010 & \\
\hline $22 \%$ & $2 \%$ & $27 \%$ & $49 \%$ & 1970-2000 & \multirow{2}{*}{$\begin{array}{l}\text { Qastal al- } \\
\text { Ma'af }\end{array}$} \\
\hline $23 \%$ & $1 \%$ & $22 \%$ & $55 \%$ & 2001-2010 & \\
\hline $19 \%$ & $2 \%$ & $28 \%$ & $51 \%$ & 1970-2000 & \multirow{2}{*}{ Salanfa } \\
\hline $16 \%$ & $2 \%$ & $25 \%$ & $56 \%$ & 2001-2010 & \\
\hline
\end{tabular}

Gumbel distribution represents potential values of the changes in the mean extreme precipitation amounts (more or less than 5\% from each side) during the period 2001-2010 
compared to 1970-2000. Using the Gumbel distribution, one can trace out the presence of different models for the changes in potential density of precipitation in the six stations (Figure 4). Figure 4a shows that in Latakia station, the probability of extreme precipitation values that is less than $461 \mathrm{~mm} /$ year has declined by $2.92 \%$ (decreased from $5 \%$ to 2.07 ), which is shown by the line with grey color on the right side of the curve. Moreover, the probabilities of extreme annual rainfall that is higher than $1141 \mathrm{~mm}$ in Latakia have declined by about $3.76 \%$ (from $5 \%$ to $1.24 \%$ ), shown as the black color on the left side of Figure 4a. The situation seems to be similar in Al- Hafa station as the probability of annual extreme low precipitation less than $580 \mathrm{~mL}$ has declined by $4.71 \%$ (The grey line to the right), and the probability of extreme high annual precipitation more than 1529 has declined by $4.36 \%$ (The black line to the left of Figure 4e). Both Salanfa and Qastal alMa'af high-altitude stations witnessed a decline in the probability of extremely high and low annual precipitation values; the decline in extreme low precipitation value of less than $803 \mathrm{~mm}$ in Salanfa reached $4.93 \%$, and the extreme high precipitation (more than $1720 \mathrm{~mm}$ ) reached $2.82 \%$ (Figure $4 \mathrm{f}$ ). Similar trend can be observed in Qastal al- Ma'af station where the probability of extreme precipitation less than $674 \mathrm{~mm}$ declined by $1.28 \%$, and the probability of extreme precipitation higher than $1542 \mathrm{~mm}$ has declined by $3.67 \%$ (Figure 4d).
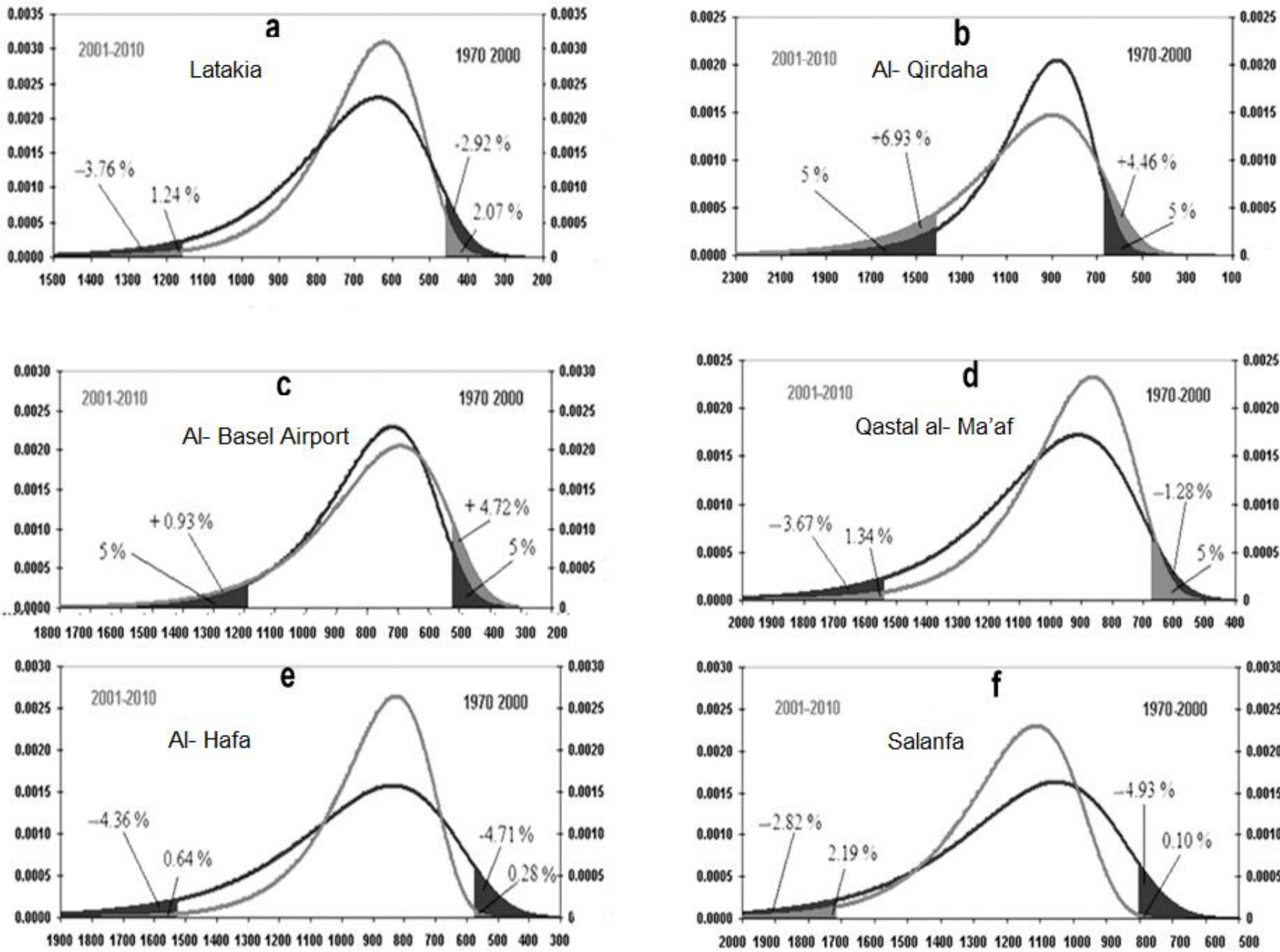

Precipitation $(\mathrm{mm})$

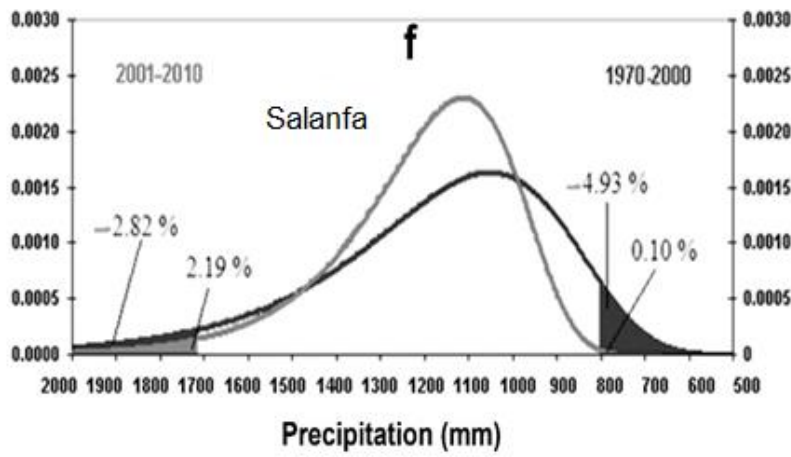

Figure 4. Changes in the potential probability of the annual precipitation average during both time-periods. (a) Latakia; (b) Al- Qirdaha; (c) Al- Basel airport; (d) Qastal al-Ma'af; (e) Al- Hafa; (f) Salanfa. 
The situation is different for Al- Basel airport and Al- Qirdaha stations. This is because of the increase in the probability of extremely high and low precipitation values. For example, in Al- Basel airport station, the probability of extreme precipitation less than $540 \mathrm{~mm} /$ year increased by $4.72 \%$ (the grey color on the right side of Figure $4 \mathrm{c}$ ), also the probability of extreme annual precipitation of more than $1192 \mathrm{~mm} /$ year slightly increased by $0.93 \%$, represented by the grey color on the left side of Figure $4 \mathrm{c}$. In Al- Qirdaha station, the probability of extreme annual precipitation of less than $681 \mathrm{~mm} /$ year increased by $4.46 \%$ (right side of Figure $4 \mathrm{~b}$ ) and the probability of extreme precipitation with more than $1410 \mathrm{~mm}$ /year (Figure $4 \mathrm{~b}$ ) increased by about 6.93 (has changed from 5\% to $11.93 \%$ ).

Generally speaking based on the aforementioned results, it could be said that the climate is improving in any station where a decrease in probability of extreme low precipitation than a certain value occurred (like in Latakia, Al- Hafa, Salanfa and Qastal al- Ma'af). Similar generalization could be applied when the probability of extreme value of precipitation more than a certain value increases (like what happened in Al- Basel airport and alQirdaha). On the contrary, when the probability of extreme low value of precipitation than a certain level increases (like in Al- Basel airport and al- Qirdaha stations) or the probability of extreme high value than a certain level decreases (like in Latakia, Al- Hafa, Salanfa and Qastal al Ma'af), then it could be said that the climate is deteriorating. As a result, the only stations that witnessed an improvement in the precipitation and its probability during the second time-period (2001-2010) are Al- Basel airport and Al- Qirdaha stations, whereas the other four stations witnessed a deterioration of the climatic conditions in the second time-period. The stations that have witnessed an improvement in the precipitation (AlBasel and Al- Qirdaha) are located in the southern part of Latakia governorate (Figure 1). Hence, this improvement can be attributed mainly to two reasons; the first is that these two stations are located in low-altitude plains with no topographic obstacles to precipitation; and the second is that there is no interfering high mountains areas to the rainy clouds from the eastern parts of the Mediterranean. Hence, for the four stations (Latakia, AlHafa, Salanfa and Qastal al Ma'af) that witnessed a decrease in precipitation, there are high mountainous areas that could prevent rich-water vapor clouds and the associated precipitation from reaching the area of such these stations.

On a seasonal level, Figure 5 represents the changes in the probability of precipitation based on Gumbel distribution during winter and spring in all the stations. The analysis focused only on spring and winter seasons because they have witnessed the most prominent changes in precipitation. Previous analysis showed a decline in the precipitation during spring, and within this season, there is an increase in the probability of extremely low precipitation amounts between 5.91\% and up to $32.3 \%$ (Figure 5) during the period 2001-2010 (the grey color on the left side of the curve). These amounts did not have a probability of more than 5\% during the period 1970-2000. The highest percentage of decline in the probability of extremely low spring precipitations has been witnessed in Latakia station (Figure 5a), and this is because the probability of precipitation of less than $73 \mathrm{~mm}$ increased by almost 6.4 times that in the first time-period (changed from 5\% to $37.26 \%$ with an increase of $32.3 \%$ ). In addition, the probability of low marginal values of precipitation has increased by 14.8\% in Qastal al- Ma'af and 13.9\% in Al- Basel airport. In the rest of the stations, the decrease is less than $9 \%$, hence it one can conclud from the previous reductions that spring is continuously becoming drier, with a shorter wet period and a more integration of spring with the summer.

On the other hand, probabilities of extremely low precipitations during winter has witnessed a decline by $5 \%$ in all the six stations except for al- Qirdaha station, in which the decline in winter precipitation did not exceed $1.7 \%$ (Figure $5 \mathrm{c}$ ). The probability of extreme precipitation with less than $169 \mathrm{~mm}$ in Latakia, less than $210 \mathrm{~mm}$ in Al- Basel airport, less than $207 \mathrm{~mm}$ in al- Hafa, less than $267 \mathrm{~mm}$ in al- Qirdaha, less than $233 \mathrm{~mm}$ in Qastal alMa'af, and less than $340 \mathrm{~mm}$ in Salanfa has reduced. In this way of change, the precipitation becomes higher during winter especially that the probabilities of low marginal values of precipitation that did not exceed $5 \%$ probability declined in all of the stations during winter 
season except for al- Qirdaha station. Such a decline in probabilities means an increase in winter precipitation rate, as compared to the total annual precipitation during the period 2001-2010 in comparison with 1970-2000 period.
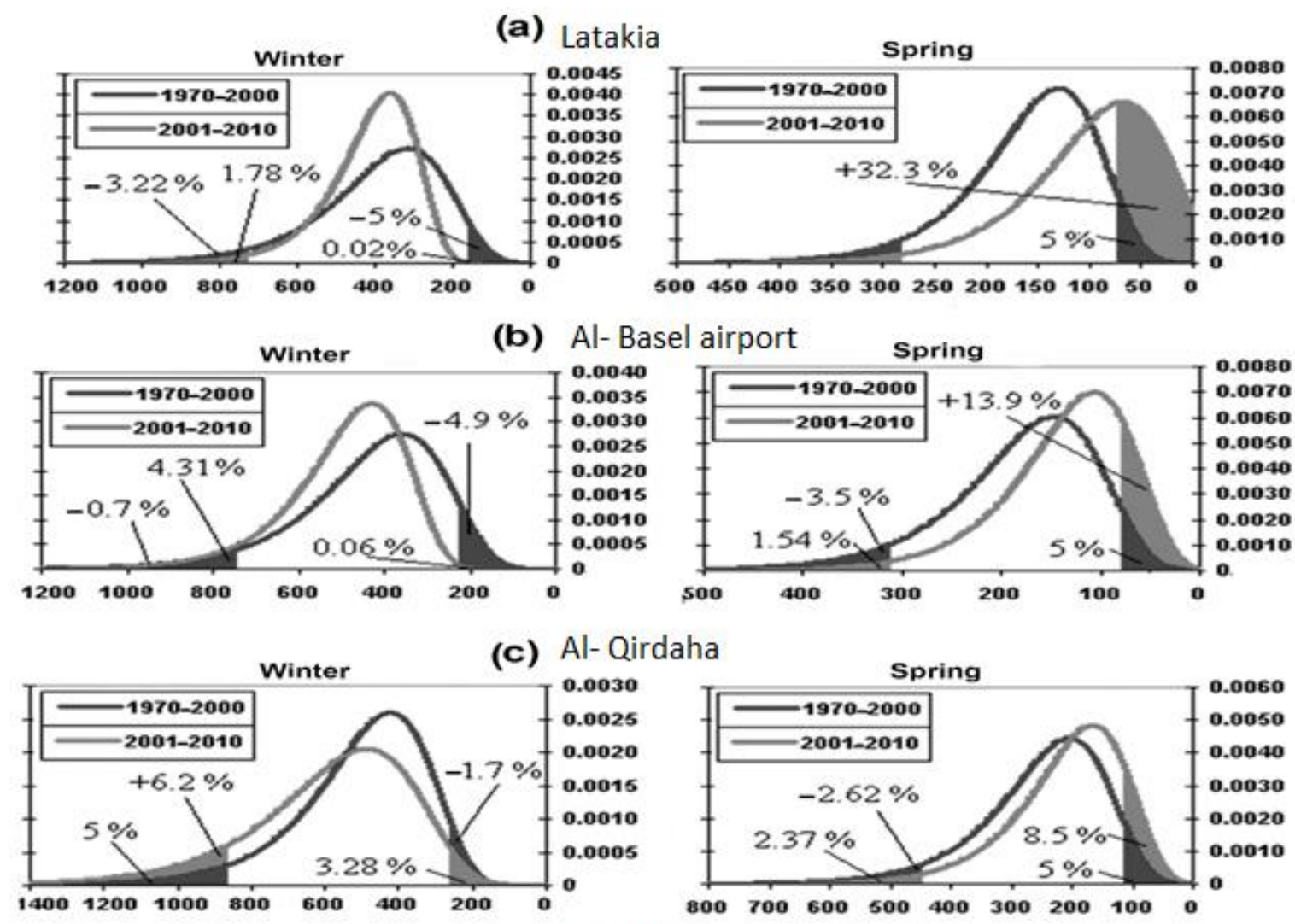

(d) Al- Hafa
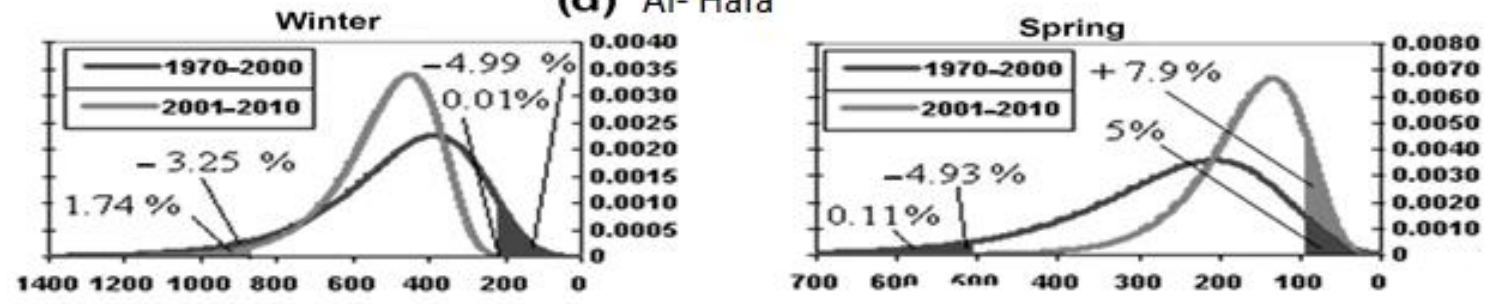

(e) Qastal al- Ma'af
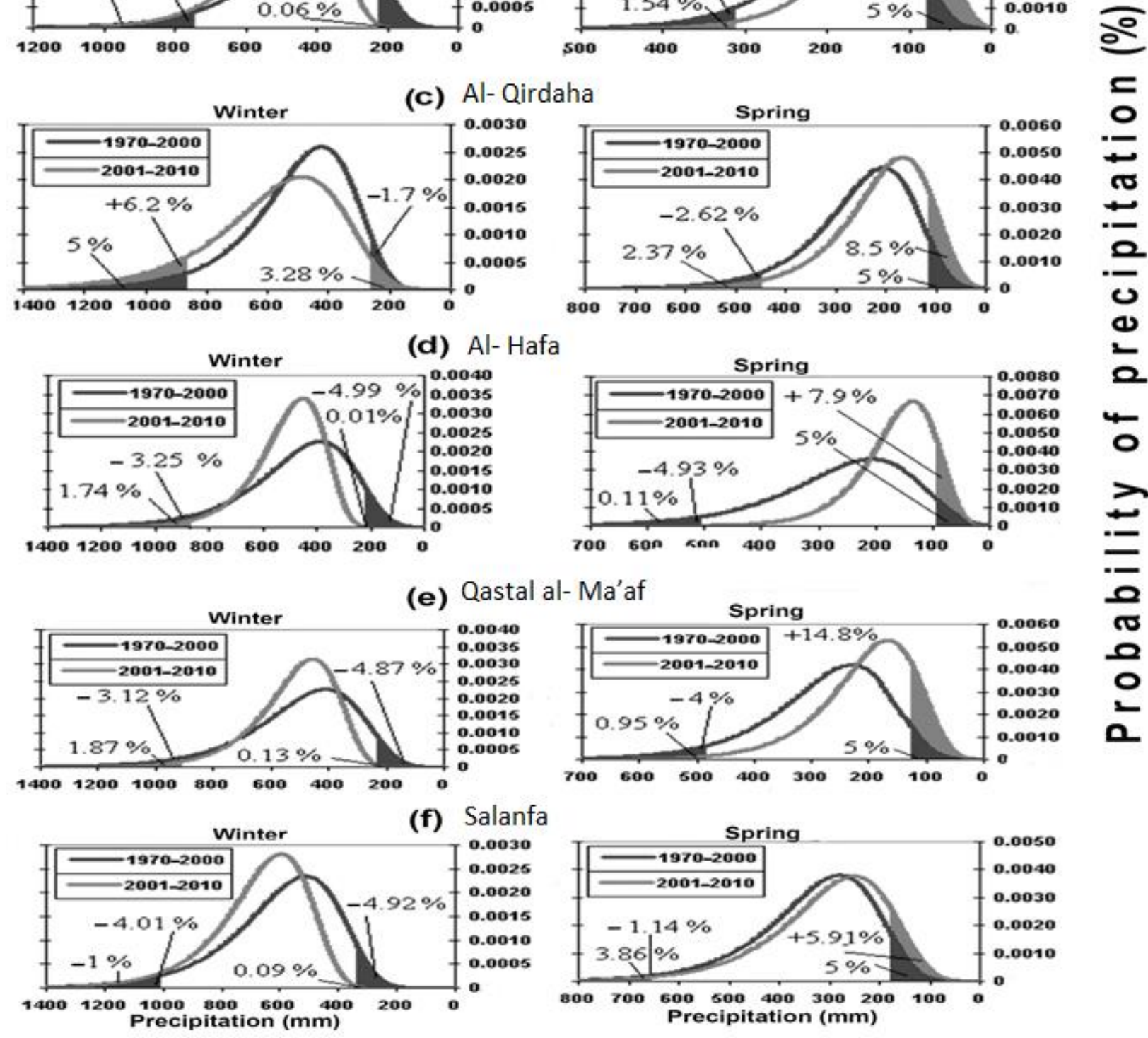

Figure 5. Changes in the potential probability of the annual average precipitation during spring and winter seasons in both time-periods. (a) Latakia; (b) Al- Basel airport; (c) Al- Qirdaha; (d) Al- Hafa; (e) Qastal al- Ma'af; (f) Salanfa. 
Kutiel found in a study of four stations in the eastern Mediterranean during 1864-1991 [40] an increasing tendency in precipitation in Jerusalem (400 km south of Latakia) during winter season and a decreasing tendency of precipitation during spring season, which are almost similar results as the current research. Kutiel also found that the most important and longest dry sequence occurred during the last 14 years of the study (1980 onward). The drying conditions started in the southern station of Jerusalem, and then has progressed northward to Athens [43]. In a study on the occurrence of extreme precipitation in the eastern Mediterranean region, the study employed three climatic indices; the maximum number of consecutive wet days, the maximum number of consecutive dry days, and the proportion of precipitation amount of wet days to the number of wet days of the period. These indices were taken in the current time as well as for future period, and on a seasonal and annual basis. The study found general future tendency of dryness into the eastern Mediterranean, with a reduction in rainfall intensity. Longer dry periods are expected in all seasons with the exception of autumn season, and the largest increase in dryness was in the southern part of the Mediterranean [44].

\section{Conclusions and Recommendations}

Based on the aforementioned discussion, the following conclusions are important to be mentioned:

1. Negative change in the mean annual precipitation in most of the stations occurred, but the changes were non-significant. The decrease in the mean annual precipitation occurred in Latakia, Al- Basel airport, Al- Hafa and Qastal al- Ma'af stations, which ranged from $14 \mathrm{~mm}$ in Latakia to $79 \mathrm{~mm}$ in Qastal al- Ma'af. Whereas in Salanfa and al-Qarirdaha stations, there was an increases of 23 and $58 \mathrm{~mm}$, respectively.

2. The regression line of spring precipitation has declined during the period 2001-2010 in all the stations, and this decline was statistically significant in Al- Hafa, Qastal alMa'af, Latakia, and Al- Basel airport. The decline was not significant in Salanfa and al-Qirdaha stations.

3. Statistical insignificant increase in winter precipitation in all of the stations that ranged between 17-86 $\mathrm{mm}$.

4. A decline in spring's share from the total annual precipitation of about 3-9\%, but an increase in the winter precipitation of $5-8 \%$, with the most prominent change occurred in Al- Hafa station.

5. Gumbel distribution for extremely high and low marginal precipitation values during the periods 2001-2010 compared to 1970-2000 showed a decline in the probability of high and low precipitation in Latakia, Al- Hafa, Salanfa, and Qastal al- Ma'af stations, while Al- Basel airport and Al- Qirdaha stations have witnessed an increase in the probability of extremely high and low values. Based on this, the only stations that witnessed an improvement in the precipitation and its probability during the second time-period (2001-2010) were Al- Basel airport and Al- Qirdaha stations, whereas the other four stations witnessed a deterioration of the climatic conditions.

6. A decline in the precipitation during spring is noticeable. This decline was accompanied with an increase in the probability of extremely low precipitation of $5.91-32.3 \%$; the highest probability of extremely low spring precipitations decline was in Latakia station, and this lead to conclusion that the spring-wet period is shorter with more integration into summer.

7. On the other hand the probabilities of extremely low precipitation values has witnessed a decline during winter by $5 \%$ in most of the stations, so that the precipitation became concentrated more in winter, which contributed to an increase in mean winter precipitation from the total annual precipitation during the period 2001-2010 compared to the period 1970-2000. 


\section{Recommendations}

1. The current study analyze only the precipitation extremes in some stations of Latakia governorate without analyzing the changes in temperature. This warrant studying temperature changes and its relation to drought and precipitation changes, which will give more accurate results about seasonal and annual level of dryness.

2. Researchers are advised to expand the study to include more stations than those studied in the current research, in order to produce accurate spatio-temporal rain and temperature maps, which can provide an insight on the spatial distribution of dryness and humidity into the governorate.

3. Due to the extended drying conditions in spring, researches on the consequences on land use and associated tools to release and suiting up effects to new land uses are essential.

Author Contributions: Conceptualization: A.H.Y.A.H. and R.Q.F.; Formal analysis: A.A.M.S. and R.Q.F.; Writing一review and editing: A.H.Y.A.H. and R.Q.F.; Data curation: R.Q.F. and A.H.Y.A.H. All authors have read and agreed to the published version of the manuscript.

Funding: This research received no external funding.

Conflicts of Interest: The authors declare no conflict of interest.

\section{References}

1. Asakereh, H. Decadal variation in precipitation regime in northwest of Iran. Theor. Appl. Climatol. 2020, 139, 461-471. [CrossRef]

2. Katiraie-Boroujerdy, P.; Ashouri, H.; Hsu, K. Trends of precipitation extreme indices over a subtropical semi-arid area using PERSIANN-CDR. Theor. Appl. Climatol. 2017, 130, 249-260. [CrossRef]

3. Lang, H.; Baltensweiler, A.; Gurtz, J.; Schulla, J. Die Auswirkung von Klimaänderung auf den Komponenten des Wasserkreislaufs. Klimaänderung und Wasserwirtschaft; Internationales Sympo-sium für Klimaänderung und Wasserwirtschaft im Europäschen Patentamt: München, Germany, 1996; pp. S73-S76.

4. Stagl, J.; Mayr, E.; Koch, H.; Hattermann, F.F.; Huang, S. Effects of Climate Change on the Hydrological Cycle in Central and Eastern Europe. In Managing Protected Areas in Central and Eastern Europe Under Climate Change; Advances in Global Change Research; Rannow, S., Neubert, M., Eds.; Springer: Dordrecht, The Netherlands, 2014; Volume 58. [CrossRef]

5. Sohoulande Djebou, D.C.; Singh, V.P. Impact of climate change on the hydrologic cycle and implications for society. Environ. Soc. Psychol. 2016, 1, 36-49.

6. Intergovernmental Panel on Climate Change (IPCC). Synthesis Report; IPCC: Geneva, Switzerland, 2007 ; p. 78.

7. Intergovernmental Panel on Climate Change (IPCC). Water and Climate Change; Working Group II; IPCC: Geneva, Switzerland, 2008; p. 49

8. Trenberth, K.E. Changes in precipitation with climate change. Clim. Res. 2011, 47, 123-138. [CrossRef]

9. Snyder, R.L.; Moratiel, R.; Zhenwei, S.; Swelam, A.; Jomaa, I.; Shapland, T. Evapotranspiration response to climate change. Acta Hortic. 2011, 922, 91-98. [CrossRef]

10. Dai, A. Drought under global warming: A review. Rev. Clim. Chang. 2011, 2, 45-65. [CrossRef]

11. Yilmaz, A.G. The effects of climate change on historical and future extreme rainfall in Antalya, Turkey. Hydrol. Sci. J. 2015, 60, 2148-2162. [CrossRef]

12. Salameh, A.; Gámiz-Fortis, A.M.; Castro Díez, Y.; Abu Hammad, A.; Esteban Parra, M. Spatiotemporal Analysis for Extreme Temperature Indices over Levant region. Int. J. Climatol. 2019, 39, 5556-5582. [CrossRef]

13. Salameh, A.; Gámiz-Fortis, A.M.; Castro Díez, Y.; Esteban Parra, M. Spatio-Temporal Analysis of Maximum and Minimum Temperatures over Levant Region (1987-2017); Agencia Estatal de Meteorología; Publicaciones de la Asociación Española de Climatología: Madrid, Spain, 2020.

14. Abu Hammad, A.; Salameh, A.M. Temperature Analysis as an Indicator of Climate Change in the Central Palestinian Mountains. Theor. Appl. Climatol. 2018, 36, 1453-1464. [CrossRef]

15. AlSarmi, S.; Washington, R. Recent observed climate change over the Arabian Peninsula. J. Geophys. Res. 2011, 116, D11109. [CrossRef]

16. Hochman, A.; Mercogliano, P.; Alpert, P.; Saaroni, H.; Bucchignani, E. High-resolution projection of climate change and extremity over Israel using COSMO-CLM. Int. J. Climatol. 2018, 38, 5095-5106. [CrossRef]

17. Najafi, M.R.; Moazami, S. Trends in total precipitation and magnitude-frequency of extreme precipitation in Iran, 1969-2009. Int. J. Climatol. 2017, 36, 1863-1872. [CrossRef]

18. Hasanean, H.M. Winter surface temperature in Egypt in relation to the associated atmospheric circulation. Int. J. Climatol. 2004, 24, 985-999. [CrossRef] 
19. Zhang, X.; Aguilar, E.; Sensoy, S.; Melkonyan, H.; Tagiyeva, U.; Ahmed, N.; Kutaladze, N.; Rahimzadeh, F.; Taghipour, A.; Hantosh, T.H.; et al. Trends in Middle East climate extreme indices from 1950 to 2003. J. Geophys. Res.-Atmos. 2005, 110 , D22. [CrossRef]

20. IPCC. Summary for policymakers. In Climate Change 2013: The Physical Science Basis (Contribution of Working Group I to the Fifth Assessment Report of the Intergovernmental Panel on Climate Change); Cambridge University Press: Cambridge, UK, 2013.

21. Seager, R.; Liu, H.; Henderson, N.; Simpson, I.; Kelley, C.; Shaw, T. Causes of increasing aridification of the Mediterranean region in response to rising greenhouse gases. J. Clim. 2014, 27, 4655-4676. [CrossRef]

22. Spinoni, J.; Vogt, J.V.; Naumann, G.; Barbosa, P.; Dosio, A. Will drought events become more frequent and severe in Europe? Int. J. Climatol. 2018, 38, 1718-1736. [CrossRef]

23. Avni, Y.; Porat, N.; Plakht, J.; Avni, G. Geomorphic changes leading to natural desertification versus anthropogenic land conservation in an arid environment, the Negev Highlands. Isr. Geomorphol. 2006, 82, 177-200. [CrossRef]

24. Simone, S. Adapting to Climate Change in the Water Sector in the Mediterranean: Situation and Prospects; Plan Bleu, UN Environment: Paris, France, 2011.

25. Black, E. The impact of climate change on daily precipitation statistics in Jordan and Israel. Atmos. Sci. Lett. 2009, 10, 192-200. [CrossRef]

26. Lelieveld, J.; Hadjinicolaou, P.; Kostopoulou, E.; Chenoweth, J.; El Maayar, M.; Giannakopoulos, C.; Hannides, C.; Lange, M.A.; Tanarhte, M.; Tyrlis, E.; et al. Climate change and impacts in the Eastern Mediterranean and the Middle East. Clim. Chang. 2012, 114, 667-687. [CrossRef]

27. Droogers, P.; Immerzeel, W.W.; Terink, W.; Hoogeveen, J.; Bierkens, M.F.P.; Van Beek, L.P.H.; Debele, B. Water resources trends in Middle East and North Africa towards 2050. Hydrol. Earth Syst. Sci. 2012, 16, 1-14. [CrossRef]

28. Cafiero, C. Study on Supply and Demand Prospects for the Major Syrian Agricultural Products; 8-9 Reports; Ministry of Agriculture and Agrarian Reform (NAPC): Damascus, Syria, 2009.

29. Erian, W.; Abbashar, A.; Abo-Swaireh, L. Drought Vulnerability in the Arab Region-Case Study Drought in Syria; Ten Years of Scarce Water (2000-2010); ACSAD: Damascus, Syria, 2011.

30. Ministry of Water and Irrigation (MWI). Water for Life: Jordan's Water Strategy 2008-2022; Ministry of Water and Irrigation: Amman, Jordan, 2009.

31. Hussein, H.; Natta, A.; Yehya, A.A.K.; Hamadna, B. Syrian refugees, water scarcity, and dynamic policies: How do the new refugee discourses impact water governance debates in Lebanon and Jordan? Water 2020, 12, 325. [CrossRef]

32. Zeitoun, M. Power and Water in the Middle East: The Hidden Politics of the Palestinian-Israeli Water Conflict; I.B.Tauris: London, UK, 2008.

33. Pongracz, R.; Bartholy, J.; Gelyb o Gy Szab 'o, P. Detected and Expected Trends of Extreme Climate Indices for the Carpathian Basin. Bioclimatology and Natural Hazards; Springer Science \& Business Media: New York, NY, USA, 2009.

34. Report of the Arab Forum for Environment and Development (AFED 2008 \& 2009). In Arab Environment Climate Change: Impact of Climate Change on Arab Countries; Arab Forum for Environment and Development: Beirut, Lebanon, 2009.

35. Seawright, J.; Gerring, J. Case Selection Techniques in Case Study Research A Menu of Qualitative and Quantitative Options Political Res. Q. 2008, 61, 294-308. [CrossRef]

36. Fürst, J.; Holzman, H. Wasserwirtschaft, Hydrologie und Flussgebietsmanagement; Institute für Wasserwirtchaft Hydroloie und konstuktiven Wasserbau, Universitat für Boenkultur: Wien, Austria, 2007; p. 18.

37. Camperling, C.; Leroch, K.; Fürst, J.; Holzman, H. Hydrologie; Institute für Wasserwirtchaft Hydroloie und konstuktiven Wasserbau, Universitat für Boenkultur: Wien, Austria, 2004.

38. Makhoul, H.A.; Matanyous, J.F.; Agha, N.A. Applied Statistics; Faculty of Economics, Damascus University: Damascus, Syria, 2006.

39. Jungo, P. Temperature Extreme; Organe consultatif sur les changements climatiques Beratendes Organ für Fragen der Klimaänderung: Bern, Switzerland, 2003.

40. Abu Hammad, A. Rainfall trends as an indication to climate change since the 19th century in the palestinian central mountains: Jerusalem governorate as a case study. Carpathian J. Earth Environ. Sci. 2021, 17, 59-68. [CrossRef]

41. NOAA. Drought in Syria Manmade Climate Change; NOAA: Damascus, Syria, 2011.

42. Trigo, I.F.; Davies, T.D.; Bigg, G.R. Decline in Mediterranean rainfall caused by weakening of Mediterranean cyclones. Geophys. Res. Lett. 2000, 27, 2913-2916. [CrossRef]

43. Kutiel, H.; Panagiotis, M.; Guika, S. Circulation and extreme rainfall conditions in the eastern mediterranean during the last century. Int. J. Climatol. 1996, 16, 73-92. [CrossRef]

44. Oikonomou, C.H.; Flocas, H.A.; Hatzaki, M.; Asimakopoulos, D.N.; Giannakopoulos, C. Future changes in the occurrence of extreme precipitation events in eastern mediterranean. Glob. Nest J. 2008, 10, 255-262. 